\title{
Faking Good Among Porn-Addicted Adolescents
}

\section{Dian Fairuz Izdihar ${ }^{1,2}$, Fikry Ravi Fauzi ${ }^{1,2}$, Diah Ayu Aguspa Dita², Miskatyas Putri Aransih' ${ }^{2}$,Pukovisa Prawiroharjo ${ }^{3}$, Elly Risman ${ }^{4}$, Rizki Edmi Edison ${ }^{2}$}

${ }^{1}$ Faculty of Psychology, University of Muhammadiyah Prof Dr HAMKA, Jakarta, Indonesia

${ }^{2}$ Neuroscience Center, University of Muhammadiyah Prof Dr HAMKA, Jakarta, Indonesia

${ }^{3}$ Department of Neurology, Cipto Mangunkusumo Hospital, Jakarta, Indonesia

${ }^{4}$ Kita dan Buah Hati Foundation, Jakarta, Indonesia

\begin{abstract}
Pornography content is becoming an increasingly serious problem in Indonesia, where it is suspected that around $97 \%$ of 1,600 children and adolescents have been exposed to pornography. Various efforts have been made by the government to minimize the prevalence of pornography content, such as by blocking porn-suspected sites. It is also known that the exposure of massive and periodic pornography content to children and adolescents can result in adverse effects in the form of addiction. Research results with EEG (Edison, RE., et al) and fMRI (Prawiroharjo, P., et al) have reported changes in the brain activity of children and adolescents who were suspected as having addiction to pornography content. Interestingly, there is a tendency to a phenomenon of faking good among the subjects. This article discusses the phenomenon from the perspectives of psychology and neuroscience.
\end{abstract}

Keywords:pornography, electroencephalography, fMRI, Self-report quetionnarre, faking good

\section{Introduction}

According to Oxford Dictionary (2018), pornography are printed or visual materials containing explicit description or display of sexual organs or activities that is intended to stimulate sexual excitement. According to the Law of the Republic of Indonesia Number 44 of 2008, pornography is an image, sketch, illustration, photo, writing, sound, moving image, animation, cartoon, conversation, gesture, or other forms of messages through various forms of media communication and/or performance in public, which contains obscenity or sexual exploitation that violates moral norms in the community (DPR RI, 2008). 
Indonesia is now facing an emergency state of pornography exposure in children and adolescents (Kemenko PMK, 2018) which is caused by pornographic content that is very easy to access via the Internet and social media.About $97 \%$ of 1,600 children have been exposed to pornographic content (Suryowati, 2018). In addition, around 25,000 teenagers have accessed pornographic content every day through social media access or cellphone (Frannoto, 2016).

Various efforts have been made by the government to minimize the spread of pornographic content, such as by blocking various sites. At least around 27,000 sites in 2017 have been blocked (Ferrissa, 2017) because they are considered to have content that violates the Information and Electronic Transaction Act (ITE) in Indonesia.Blocking of pornsites still continues and will not be stopped (Kominfo, 2018). Nevertheless, it is still easy for children and teenagers to access pornographic content either intentionally or not through social media or cellphones.

Exposure to pornographic content that occurs continuously in children and adolescents has a negative impact in the form of addiction behavior. Using electroencephalography (EEG) Edison et al (2018) has shown that there is a change in brain wave activity in the frontal lobes in children who experience pornography addiction compared to the non addict ones. Furthermore, Prawiroharjo et al (2018) have shown a decrease of the brain volume in children who experience pornography addiction compared to non addict children using functional magnetic resonance imaging (fMRI).

In addition to using instruments such as EEG and fMRI, psychologists also examine participants using self-report questionnaire an instrument used in a study which is completed by the participants and an interview to find out whether or not someone has experienced pornography addiction. Uniquely, the results of self-report questionnaire showed that some participants did not experience pornography addiction, while the EEG results and interviews suggested that the participants experience pornography addiction. There is a tendency for someone to answer the questions towards a better one which is known as faking good (Anastasia \& Urbina, 2007).

Therefore, this article will discuss further about the existence of faking good in children and adolescents with pornography addiction.

\section{Faking Good}

Faking is the tendency of participants to choose responses that are not in accordance with their characteristics or deliberately change the response to adjust themselves to a particular group (Setiawati, 2012). In addition, according to Paulhus (2002), participants usually pretend to be good in responding to an instruction so that they will be considered as "good people" (Pauls \& Crost, 2004). Faking good can occur due to someone's desire to get a good assessment so they will choose a good answer, even though the answer does not reflect them. Conscious effort to manipulate responses to personality attributes to make a positive impression (Zickar \& Robie, 1999).

Faking can be divided into two forms, namely faking good and faking bad. In faking good, participants give good responses that are appropriate to a particular group or community.In contrast, in faking bad, the response given by participants is a bad response (Setiawati, 2012) but still wants results that agree with community norms. According to Anastasi and Urbina (2007), when filling out the scale filled by the participants themselves, participants have a tendency to answer towards a better answer (faking good). This tendency arises with reasons to protect oneself, avoid criticism, social conformity, and the desire to be socially accepted. For example, Fals-Stewart (1995) reported that there was a tendency for faking good in participants who used addictive substances (drug abuse) to avoid addiction detection (Lenny \& Dear, 2015). In our case, pornographic content is still a sensitive issue so that it is avoided by children and adolescents.

In other words, faking good can be defined as a bias response where participants manipulate answers by changing their answers to create a positive impression (Van Hooft \& Born, 2012). This also 
happens because the results obtained from participants are not in the real situation. This inaccurate situation makes the research results inaccurate.

\section{Social Desirability (SD)}

Faking good is an effect that arises from secondary variables that are not monitored and controlled by participants. In our case, the secondary variable is a social desirability or the efforts of the participants to show a good response in accordance with the norms of society (Febrinabilah, 2016). Social desirability is the answer or individual response to the questions posed to him, where participants equalizse their responses to community characteristics (enhance some social characteristics) and avoid the characteristics that are not expected by the public (minimize the presence of some socially undesirable characteristics) (Widhiarso, 2010). In other words, social desirability is an attempt to equalize this response in order to remain good and hide bad things.

In the case of pornography, it becomes a sensitive and negative issue in the community. The children and adolescents are most likely tend to not acknowledging their involvement in viewing pornographic content because these behaviors are not in accordance with the characteristics and assumptions that are good in the community (Mahananti, 2009).

A research by Wiliam and Bernard (1974), conducted on participants who were heroin addicts, showed that there was a high social desirability in the group given stress stimuli, rewards and volunteers. The results indicated the existence of faking good in which they try to respond in accordance with the norms of the community normally.

Paulhus (1984) distinguishes Social Desirability (SD) into two types, namely impression management and self-deception (Widhiarso, 2010).

\section{Impression Management}

Impression management describes a representation of participants to increase the attractiveness of others (Widhiarso, 2010). Impression management is a part of social desirability that results in faking good behavior (Lastina \& Abidin, 2013) Where someone will show it intentionally and consciously (Ferrow et al., 2015). Tedeschi, Schlenker, and Bonama (1971) stated that behavior change is an application of impression management function. In this case, someone wants to look consistent and show an attitude to create a good impression (Gaes, Kalle \& Tedeschi, 1978).

For example, research conducted by Tom et al (2015) found results that the process of deceiving oneself and others is an indication of a person's tendency to pretend to be good (Faking Good) or faking bad. Impression management and self-deception in social desirability are different cognitive processes but cannot be separated.

\section{Self-Deception}

Different from self-deception. Self-deception can be interpreted as lie to yourself. Self-deception is lie to yourself that can also function to deceive others, can occur because of the refusal of problems, self-esteem, egocentric and repulsion and creation of desired situations (Trivers, 2002). In this case, self-deception can be a form of individual self-defense when facing stressful situations (Widhiarso, 2010) and can be biased (Trivers, 2002). Usually, self-deception will be shown unconsciously in dangerous situations (Ferrow, et al, 2015).

In the case of pornography addiction, a person who faces a threatening situation as he is being asked questions about pornographic content will deceive by saying no unconsciously. In other cases, someone who drinks alcohol thinks that the drink is good, or a mother believes her child is a good child, even though a criminal. According to Trivers' hypothesis, there are indications of self-deception ability that is raised, it evolves to deceive others (Ferrow, et al, 2015). 


\section{Conclusion}

Faking good is a phenomenon that is found as a form of self-protection from criticism and desire to be recognized in the social sphere. Faking good arises due to lack of control on secondary variables. In this case, the secondary variable is social desirability. Therefore, participants will tend to answer questions towards better things in order to get a good assessment as well as an effort to equalize the response to community norms and characteristics which can lead to bias. So, it is very important to monitor or control secondary variables from participants who can indicate bias.

In addition, from the results found in identifying participants, other tools can be used to reinforce data objectivity such as neuroimaging tools (electroencephalography, fMRI, etc)

\section{References}

Abidin, Zaenal, Fiona Fisabillia Lastina. 2013. Hubungan Antara Dukungan Sosial dengan Kecemasan Menghadapi Ujian Nasional pada Siswa SMA Negeri 2 Kota Magelang. Semarang. University of Diponegoro

Anastasi, A \& Urbina. (2007). Tes Psikologi:Terjemahan. Jakarta: PT Indeks

Blocking sites, access on https://kominfo.go.id/content/detail/1649/kemenkominfo-pemblokiran-situsporno-tak-akan-dihentikan/0/sorotan media at 10 October 13, 2018

Capel, William C., Bernard Caffrey. 1974. Faking Good as a Problem in Comparative Studies of Heroin Addicts. Clemson University

Farrow, Tom F. D, Jenny Burgess, Iain D. Wilkinson, Michael D. Hunter. 2015. Neural Correaltes of Selfdeception and Impression-management. University of Sheffield

Febrinabilah, Rizki. 2016. Hubungan antara Self Compassion dengan Resiliensi pada Mantan Pecandu Narkoba Dewasa Awal. Jakarta. University of Yarsi

Griffin, Barbara, Ian G Wilson. 2012. Faking Good: Self-enhancement in Medical School Applicants. Medical Education.

Mahanani, Tri. 2009. Pengaruh Partisipasi Anggaran Terhadap Kinerja Manajerial dengan Self Efficacy, Social Desirability, dan Organizational Commitment sebagai Variabel Intervening. Surakarta. University of Sebelas Maret

Pauls, Cornelia A., Nicolas W. Crost. 2004. Effectsof Faking on Self-deception and Impression Management Scales. Germany. University of Marburg.

Pornography, access on https://nasional.tempo.co/read/768513/menteri-yohana-25-ribu-remaja-aksespornografi-tiap-hari at 10 October 13, 2018

Pornography Definition, access on https://id.oxforddictionaries.com/ at 10 October 13, 2018

Pornography Emergency, access on https://www.kemenkopmk.go.id/artikel/darurat-pornografikemenko-pmk-perkuat-koordinasi-pencegahan at 10 October 13, 2018

Setiawati, Farida Agus. 2012. Paired Comparison sebagai Sebuah Model Instrument untuk Menggali Karakteristik Nonkognitif Siswa. Yogyakarta state University

Survey KPPPA, access on https://www.jawapos.com/nasional/humaniora/17/03/2018/mengejutkansurvei-kpppa-sebut-97-persen-anak-sd-terpapar-pornografi at 10 October 13, 2018 
Undang-undang Republik Indonesia Number 44 about pornography content.

Van Hooft, Edwin A. J. 2012. Intentional Response Distortion on Personality Tests: Using Eye-Tracking to Understand Response Processes When Faking. Journal of Applied Psycholog, American Psychological Association

Widhiarso, Wahyu. 2011. Aplikasi Teori Respon Butir Untuk Menguji Invariansi Pengukuran Psikologi Guna Keperluan Survei dan Seleksi Pekerjaan. Yogyakarta. University of Gadjah Mada 